\title{
Phytochemical and Anthelmintic Investigation of Leaves of Glochidion ellipticum Linn
}

\author{
Jawarkar SV ${ }^{1}$ and Kane SR ${ }^{2}$ \\ ${ }^{1}$ Department of Pharmaceutical Chemistry, S. D. Patil Institute of Pharmacy, Maharashtra, India \\ ${ }^{2}$ Department of Pharmaceutical Chemistry, Rajarambapu College of Pharmacy, Maharashtra, India
}

Corresponding author: Kane SR, Department of Pharmaceutical Chemistry, Rajarambapu College of Pharmacy, Maharashtra, India, Tel: +91 9960022448; E-mail: kanesandeep@gmail.com

Received Date: January 23, 2017; Accepted Date: March 13, 2017; Published Date: March 20, 2017

Copyright: (C) 2017 Jawarkar SV, et al. This is an open-access article distributed under the terms of the Creative Commons Attribution License, which permits unrestricted use, distribution, and reproduction in any medium, provided the original author and source are credited.

Citation: Jawarkar SV, Kane SR. Phytochemical and Anthelmintic Investigation of Leaves of Glochidion ellipticum Linn. Eur Exp Biol. 2017, 7:9.

\section{Abstract}

Worm infections remain a major constraint to livestock productivity across all agro-ecological Zones. Now, the main mode for control of gastrointestinal parasites is based on the synthetic anthelmintic. However, wide spread increase of anthelmintic resistance, scarcity and high cost especially to farmers of low income in developing countries led to the need of other alternative helminth control methods. Among other alternative methods, there is considerable and expanding interest in traditional herbal de wormers. In present communication methanolic and aqueous extracts of leaves of Glochidion ellipticum Linn. Flem were investigated for their anthelmintic activity against Pheretima posthuma and Ascardia galli. Different concentrations were used in the assay, which involved paralysis and death time of the worms. Both the extracts showed significant anthelmintic activity.

Keywords: Ascardia galli; Pheretima posthuma; leaves of Glochidion ellipticum Linn; Piperazine citrate

\section{Introduction}

Nature is best combinatorial logical master and conceivably has answers to all contaminations of humanity [1]. Till now, normal thing blends found from restorative plants have given different clinically supportive solutions [2]. In India itself, there are more than 1100 remedial plants grew all around all through wild woods. Of these, precisely 60 geneses are used hugely as piece of therapeutic courses of action [3]. Glochidion is to great degree limitless assortment under which more than 250 species are accessible. By far most of species under this assortment is by and large constituted with flavonoids and triterpenoid, saponins. This social event of plants are comprehended among tribes for it's against tumor, hypotensive, diuretic and diverse properties [4].

Glochidion was seen as kind of family Euphorbiaceae. Similarly lots of studies have been done on phyllanthus genra on Glochidion species in family Phyllanthaceae. Several right hand metabolites were obliged from accumulated Glochidion species, including tannins, glycosides, lignans, terpenoids [5]. There are more than 250 sorts of plant on planet. In long run, significant piece of creature classes are yet to be gotten some data about or must be continued to light of pros. Couple triterpenoids and triterpenoids glycosides and alkaloids are known not constituents of plants having spot with game-plan Glochidion plants having triterpenoid are most exhaustively used for treatment of disease. In India unmistakable supportive plants and their unassuming areas are for most part used for treatment of coordinated issue [5]. Glochidion ellipticum Linn. Fever nut; bonduc nut (Family: Euphorbiaceae) commonly known as Nata Karanja (Hindi), is a prickly shrub found throughout the hotter regions of India, Myanmar and Sri Lanka. By performing chemical tests revealed that extract consist of secondary metabolites like diterpines, resins, flavonoids, tannins and steroids. The main intention of study is to evaluate anthelmintic potential of leaves of Glochidion ellipticum Linn.

\section{Materials and Methods}

\section{Plant material}

The whole plant Glochidion ellipticum Linn were collected from karad-patan hills near Satara district of Maharashtra. Plant was authenticated by Dr. Sanjay S. Sathe, department of Botany, Padmabhushan Dr. Vasantraodada Patil Mahavidyalaya, Tasgaon, Dist-Sangli, Maharashtra.

\section{Preparation of extracts}

The leaves were collected in summer session, shade dried, powdered and used for extraction. First chlorophyll was removed by treatment of petroleum ether and cold macerated.

\section{Animals}

Indian adult earthworms Pheretima posthuma \& Ascardia galli were collected from freshly slaughtered fowls. Both worms were authenticated from Raja Lakhamagouda Science Institute, Belgaum. 


\section{Evaluation of anthelmintic activity}

Activity was performed as per Ajaiyeoba et al. method [6]. The relative biological activity was evaluated on adult Indian earth worm Pheretima posthuma [7] \& Ascardia galli [8]. From three different concentrations alcoholic and aqueous extract $(10,100,200 \mathrm{mg} / \mathrm{ml}$ in distilled water) was treated for the study of anthelmintic activity (paralysis \& death), six worms (same type) were placed in it. Observations were made for both type of worms and the time taken to cause paralysis and death of the individual worms calculated. Mean time for paralysis \& death time was recorded; piperazine citrate $(10 \mathrm{mg} / \mathrm{ml})$ was used as reference standard [9-11] (Tables 1 and 2).

Table 1 Phytochemical investigation of leaves of Glochidion ellipticum Linn.

\begin{tabular}{|l|l|l|}
\hline S. No & Test & Present(P)/Absent(A) \\
\hline 1. & Carbohydrates & A \\
\hline 2. & Alkaloids & A \\
\hline 3. & Glycosides & P \\
\hline 4. & Diterpenoids & P \\
\hline 5. & Flavonoids & P \\
\hline 6. & Resins & P \\
\hline 7. & Tannins & Pteroids \\
\hline 8. & & \\
\hline
\end{tabular}

Table 2 Anthelmintic investigation of leaves of Glochidion ellipticum Linn.

\begin{tabular}{|c|c|c|c|c|c|c|}
\hline \multirow{2}{*}{ Sr. No } & \multirow{2}{*}{ Compounds } & \multirow{2}{*}{$\begin{array}{l}\text { Conc. } \\
\text { (mg/ml) }\end{array}$} & \multicolumn{4}{|c|}{ Time for respective activity } \\
\hline & & & Paralysis (P) & Death (D) & Paralysis (P) & Death (D) \\
\hline 1. & Control & - & - & - & - & - \\
\hline \multirow{3}{*}{2.} & \multirow{3}{*}{ Alcoholic extract LGE } & 10 & $26.5 \pm 0.56$ & $65.0 \pm 0.36$ & $29.67 \pm 0.42$ & $48.22 \pm 0.54$ \\
\hline & & 100 & $17.0 \pm 0.56$ & $45.5 \pm 0.42$ & $18.92 \pm 0.50$ & $35.40 \pm 0.41$ \\
\hline & & 200 & $8.66 \pm 0.49$ & $29.5 \pm 0.45$ & $09.45 \pm 0.45$ & $29.75 \pm 0.55$ \\
\hline \multirow{3}{*}{3.} & \multirow{3}{*}{ Aqueous extract LGE } & 10 & $29.17 \pm 0.47$ & $67.83 \pm 0.60$ & $20.81 \pm 0.46$ & $51.06 \pm 0.58$ \\
\hline & & 100 & $19.37 \pm 0.71$ & $50.67 \pm 0.66$ & $12.35 \pm 0.45$ & $38.25 \pm 0.54$ \\
\hline & & 200 & $07.66 \pm 0.33$ & $32.33 \pm 0.65$ & $08.10 \pm 0.64$ & $29.25 \pm 0.58$ \\
\hline 4. & Piperazine citrate & 10 & $18.83 \pm 0.85$ & $60.33 \pm 0.58$ & $15.71 \pm 0.46$ & $41.64 \pm 0.75$ \\
\hline
\end{tabular}

\section{Results and Discussion}

Phytochemical screening of leaves of Glochidion ellipticum Linn showed the presence of diterpenoids, flavonoids, steroids, tannins and resins. As shown in Table 1, alcoholic and aqueous extract exhibited anthelmintic activity in dose-dependent manner giving shortest time of paralysis (P) and death (D) with $200 \mathrm{mg} / \mathrm{ml}$ concentration. The alcoholic extract of leaves of Glochidion ellipticum Linn caused paralysis of $8.66 \mathrm{~min}$. and time of death of $29.5 \mathrm{~min}$. while aqueous revealed paralysis of 7.66 and $32.33 \mathrm{~min}$. respectively against the earthworm Pheretima posthuma. The reference drug Piperazine citrate showed the same at 18.83 and 60.33 minutes, respectively. Ascardia galli worms also showed sensitivity to the methanolic and aqueous extract of leaves of Glochidion ellipticum Linn. The methanolic extract caused paralysis in $09.42 \mathrm{~min}$, death in $29.75 \mathrm{~min}$ and the aqueous extract displayed $P$ and $D$ in 08.10 and $29.22 \mathrm{~min}$, respectively at higher concentration of $200 \mathrm{mg} / \mathrm{ml}$. Piperazine citrate did the same at 15.17 and $41.67 \mathrm{~min}$. Piperazine citrate act with its own mechanism of action by increasing chloride ion conductance of worm muscle membrane produces hyper polarization and reduced excitability that leads to muscle relaxation and paralysis.

\section{Discussion}

The leaf extract of Glochidion ellipticum Linn not only demonstrated paralysis, but also caused death of worms especially at higher concentration of $200 \mathrm{mg} / \mathrm{ml}$ in shorter time as compared to reference drug Piperazine citrate. Tannins were shown to produce anthelmintic activities chemically tannins are polyphenolic compounds. The present work was carried out on the Glochidion ellipticum linn which contains tannins. Further 
studies are in process to identify the possible phytoconstituents responsible for anthelmintic activity.

\section{Acknowledgement}

We are thankful to $\operatorname{Dr}$ C. S. Magdum, Principal Rajarambapu College of Pharmacy, Kasegaon for providing facility to this project.

\section{References}

1. Waller PJ (1997) Sustainable helminth control of ruminants in developing countries. Vet Parasitol 71: 195-207.

2. Jackson F, Coop RL (2000) The development of anthelmintic resistance in sheep nematodes. Parasitology 120: S95-S107.

3. Kane SR, Wadkar GH (2010) In vitro anthelmintic activity of Caesalpinia bonducella (Linn). Flem. Leaves. J Pharmacy Research 3: 926-927.

4. Sandhya S, Chaintanya RSNAKK, Vinod KR, Rao KNV, David Banji, et al. (2010) An updated review on the Genus Glochidion Plant. Archives of Applied Sci Res 2: 309-322.
5. Azam ATMZ, Al Hasan A, Uddin MG, Masud MM, Hassan CM (2012) Antimicrobial, Antioxidant and Cytotoxic Activities of Glochidion multiloculare (Roxb. ex Willd.) Müll Arg (Euphorbiaceae). Dhaka Univ J Pharm Sci 11: 117-120.

6. Neogi NC, Nayak KA (1958) Biological investigation of Caesalpinia bonducella F. Indian J Pharmacol 20:95-100.

7. Dhar ML, Dhar MM, Dhawan BN, Mehrotra BN, Ray C (1968) Screening of Indian plants for biological activity: I. Indian J Exp Biol 6: 232-247.

8. Gayaraja S, Shinde S, Agarwal SL (1978) Antiasthmatic properties of Caesalpinia bonducella Leaves. Indian J Pharmacol 10: 86-88.

9. Ajaiyeoba EO, Onocha PA, Olarenwaju OT (2001) In vitro anthelmintic properties of Buchholzia coiaceae and Gynandropsis gynandra extract. Pharm Biol 39: 217-220.

10. Thorn GW, Adams RD (1997) Harriasons Principles of Internal Medicine. McGraw Hill Co., New York.

11. Khandelwal KR (2008) Practical Pharmacognosy. Nirali Publication House 25: 1-25. 